\title{
Managerial Challenges Impacting on a TBM Design: A Kingdom of Saudi Arabia Metro Project
}

\author{
Paul James ${ }^{1}$ \\ ${ }^{1}$ Graduate School Bangkok University, Bangkok, Thailand \\ Correspondence: Paul James, Graduate School Bangkok University, Bangkok, Thailand. E-mail: paul.j@bu.ac.th
}

Received: July 15, 2014 Accepted: August 4, 2014 Online Published: October 26, 2014

doi:10.5539/emr.v3n2p32 URL: http://dx.doi.org/10.5539/emr.v3n2p32

\begin{abstract}
This paper explores the managerial challenges and viewpoints relating to the management of a metro design in KSA, raised by a group of design engineering staff. The paper examines the scope, reflections, and attitudes to the project management and which appear to contribute to the efficacy of the design outcomes between a single group of engineering personnel of thirteen (13) design engineers for a metro development in KSA. The paper advances a conceptualisation from the findings of a diverse range of qualitative personnel opinion into an integrated framework.

Outcomes from this inquiry suggests that the project management show clear issues with the management style adopted to manage this group and explores the derived themes of namely four (4) main themes, namely Management; Project, People; and Technology.

The outcomes shows opinion that the project management are not effectively managing the project corresponding with raised issues of cost/schedule overruns, delays to the project through poor coordination, ineffective leadership of the projects activities, and inadequate project preparation and its managerial execution. The paper further suggests how some of the effects of these identified issues may be reduced or mitigated.
\end{abstract}

Keywords: management, challenges, design, metro, KSA

\section{Introduction}

Project design management practices have progressively developed for many years. Nevertheless, the opportunities and the difficulties associated with project management design practices have continued to change and modify (Crawford, Pollack, \& England, 2006). Many writers perceive the need for successful collaboration between contractors and clients in large metro design projects as a contemporary prerequisite (Jaafari, 2003). Further, such large metro projects are often characterised by the development of a culture that focuses on the ambiguous (Engwall, 1998); favouring operational independence (Langfred \& Moye, 2004); raising attempts at establishing innovativeness (Rogers, 1995); building entrepreneurship (James, 2011); and exhibiting strong risk management orientations (Chapman \& Ward, 1995) through appropriate leadership attributes and behaviours (Keegan and Den Hartog, 2004). However, some large metro projects operate dysfunctionally (Bate, 1994) and project managers and others involved in the management of projects do not appear understand the projects character (Anderssen, 2003); take note of its complexity (Koot \& Sabelis, 2002); nor determine the most efficient/effective methodology to manage the life-time cycle of the project. Consequently, many projects appear to exhibit serious issues related to rising costs, haphazard scheduling and programme delivery (Flyvbjerg, Bruzelius \& Rothengatter, 2003). The resulting project managerial focus is thus influenced by increased ambiguity (Engwall, 1998); and short-term action goals, increased cost and elevated levels of stress and conflict among the many groups acting on behalf of their project partners (Pena-Mora, Sriram \& Logcher, 1995) that lead to misallocation of scarce resources (Flyvbjerg, Bruzelius, \& Rothengatter, 2003). Accordingly, when focusing on the TBM design process adopted by some project managers they often appear to exact damaging influences on the design result, cost and timing, and the client project perception (Anderssen, 2003). Further, managerial approaches to project management do not follow exact paths of implementation and are often mired in fuzzy boundaries resulting in chaotic outcomes, which can be costly and time consuming (Jaafari, 2003).

Further, contextualising the design phase as coupled design (Olson \& Olson, 2000) —which starts through an analysis of client requirements (Gunasekaran \& Love, 1998); often moves on to implying convergence to one 
solution quite early in the process (Yoo \& Chang, 2013); building the concept phase into a number of sub-phases to be undertaken sequentially (Cohen, 2010); and finally the utilisation of models for stimulating a wider solution outcome, resulting from formal evaluation processes (Thomsen et al., 2009). This aspect of the project is behaviourly characterised adhocratic (Mintzberg, 1980) when team members exhibit conflicting aims, priorities and expectations, and need to build a working culture (Koskela, 2003) that focuses on ways to discover shared goals, objectives and problem-ownership (Hastings, 1995).

\subsection{Challenges for Metro Construction Project Design Management}

A notional but very important issue is the need to engage leadership (Davenport, De Long, \& Beers, 1998). This has the effect of ensuring the project is on the right course and defined appropriately. A visible and integrated function is the management of collaboration, which can be difficult to achieve in relation to consensus-based outcomes (Cunningham, 2014); and successful multi-disciplinary interaction (Gunasekaran \& Love, 1998) leading to efficient project decision-making (Foley \& Macmillan, 2005). Further, in some metro construction projects, management evaluative competencies (Lee, Kim, \& Lee, 2011) are used to ensure progressive managerial influences are imposed on technological and project processes (Garvin, 1998) resulting in more favourable dynamic internal operating capability (Teece, Pisano, \& Shuen, 2007). These constructive managerial processes appear to enhance collaboration within Lean Construction (e.g. Ballard \& Howell, 2003), but is still vexed by the application of negative managerial culture constructs (van Marrewijk \& Veenswijk, 2006). Further, this managerial intent, critical disposition and application - assumed to be systematic and continuously applied throughout the entire construction project (Saurin, Formoso, \& Guimarães, 2004)-have great influence on project practices (Sauser, Reilly, \& Shenhar, 2009). Consequently, there appears uncertainty surrounding the managerial execution of metro construction projects (Young, 1998); perceived as controversial (Lindgren \& Packendorff, 2005); appear collectively constrained (Cicmil, 2005); which is overtly associated with project failure (Andersen, Birchall, Jessen, \& Money, 2006) through ill-managed projects (Kerzner, 1998).

In large to mega-metro construction projects, an observance can be seen in the application of computational methods to help shape design parameters (Horvath, Rusak, \& Duhovnik, 2007) - conditionally imposed through the application of new optimisation methods giving access to enhanced collaborative processes (Gobeli, Koenig, \& Bechinger, 1998). This is seen to initiate corresponding control issues (Brown \& Eisenhardt, 1997; McAnulty $\&$ Baroudi, 2010) leading to the need to manage and off-set operational contingencies (Lynn, 1998) using more focused communication practices (Szulanski, 1996) whilst engaging in attempts at enhancing risk management activities (Derelov, 2008).

This leads to the major research question: What managerial challenges and problems do design project teams experience when designing a TBM for a metro?

\section{Methodology}

To investigate the issues generated within the design context, a deeper, more involved approach was considered appropriate. In order to consider more implicitly these generated issues, this empirical foundation exploited an interpretive approach (Hill, Thompson, \& Williams, 1997; Walsh, White, \& Young, 2008). This was an attempt to understand the perceptions of design engineers of their tunnel design practices when considering a TBM design. The design engineers were considered specialist knowledge agents and actors (Benn et al., 2008) as their opinions and experiences influenced the effectiveness of TBM design practices, and the development and application of building design knowledge.

The research used a semi-structured interview conducted with design engineers, which provided an appropriate element of context and flexibility (Cassell \& Symon, 2004) and this was further aided by applying an inductive/theory building approach (Glaser \& Strauss, 1967). Given the lack of appropriately focused research in this area, this methodology is seen as suitable for creating contextual data for the purpose of forming richer theory development (Cayla \& Eckhardt, 2007).

The population frame (22) for this study was made up of a specific TBM design group (19) located at one office site, and also included international designers (3) from identified overseas locations - which is considered an existing frame (Ritchie \& Lewis, 2003) and delivered an initial means for appropriate sampling assessment with clear boundaries (Coyne, 1997). Given that not all individuals in this group were available for interview - being overseas, the sampling frame was configured from this population as being described as 17 in number, where each respondent was included (Fink, 2000), and no respondent was considered out of scope relative to the research orientation and requirements (Koerber \& McMichael, 2008). Consequently, and in line with a qualitative approach (Bryman, 2001), the respondents were chosen through applying the approach of a targeted population of interest (Carman, 1990) and this reflected the criteria of theoretical purpose, relevance and 
appropriateness (Glaser \& Strauss, 1967). Additionally, using Glaser's (2004) sampling processes, a total of 13 design engineers were thus determined as the resultant sample frame, which could also be considered convenience sampling according to Harrel and Fors (1992) and the sample frame meets the saturation requirements of Guest, Bunce, and Johnson (2006) and thus takes the sample frame beyond the expected level.

Each interview was audio recorded for future analysis. Interviews were conducted in English and took approximately one hour. All interviews were conducted through Skype and recorded digitally after gaining explicit permission (following Duranti, 2007) and were later transcribed verbatim using NVivo 11 software using the approach indicated by Bailey (2008). The conduct of the interviews follows a similar process used by Gray and Wilcox (1995), with each individual group being asked the same set of questions-modified through ancillary questioning (probes and follow-ups) in the same way as Balshem (1991). To increase the reliability of the data, the actual transcription was returned to each respondent-via e-mail-for comment, correction, addition or deletion and return, which followed the process of validated referral (Reeves \& Harper, 1981). Whole-process validity was achieved as the respondents were considered widely knowledgeable of the context and content associated with the research orientation (Tull \& Hawkins, 1990). Each interview was initially manually interrogated and coded initially using the Acrobat software according to sub-themes that 'surfaced' from the interview dialogue - using a form of open-coding derived from Glaser (1992a); and Straus and Corbin (1990). This treatment was also reinforced and extended through the use of thematic analysis conducted using the NVivo 11-qualitative software package (Walsh, White, \& Young, 2008). Each interview was treated and coded independently. In this way, no portion of any interview dialogue was left uncoded and the overall outcome represented the shared respondents views and perspectives through an evolving coding-sequence (Buston, 1999). Various themes were sensed from the use of the software packages, as well as from the initial manual-coding attempts. This dual form of interrogation was an attempt to increase the validity of the choice of both key themes and sub-themes through a triangulation process (Onwuegbuzie, Leech, \& Collins, 2012). NVivo 11 was further used to explore these sub-themes by helping to pull together each of these sub-themes from all the interviews (Harwood \& Garry, 2003). In this way, it was possible to capture each respondent's comments across transcripts (Riessman, 1993) on each supported sub-theme and place them together for further consideration and analysis (Ryan \& Bernard, 2003).

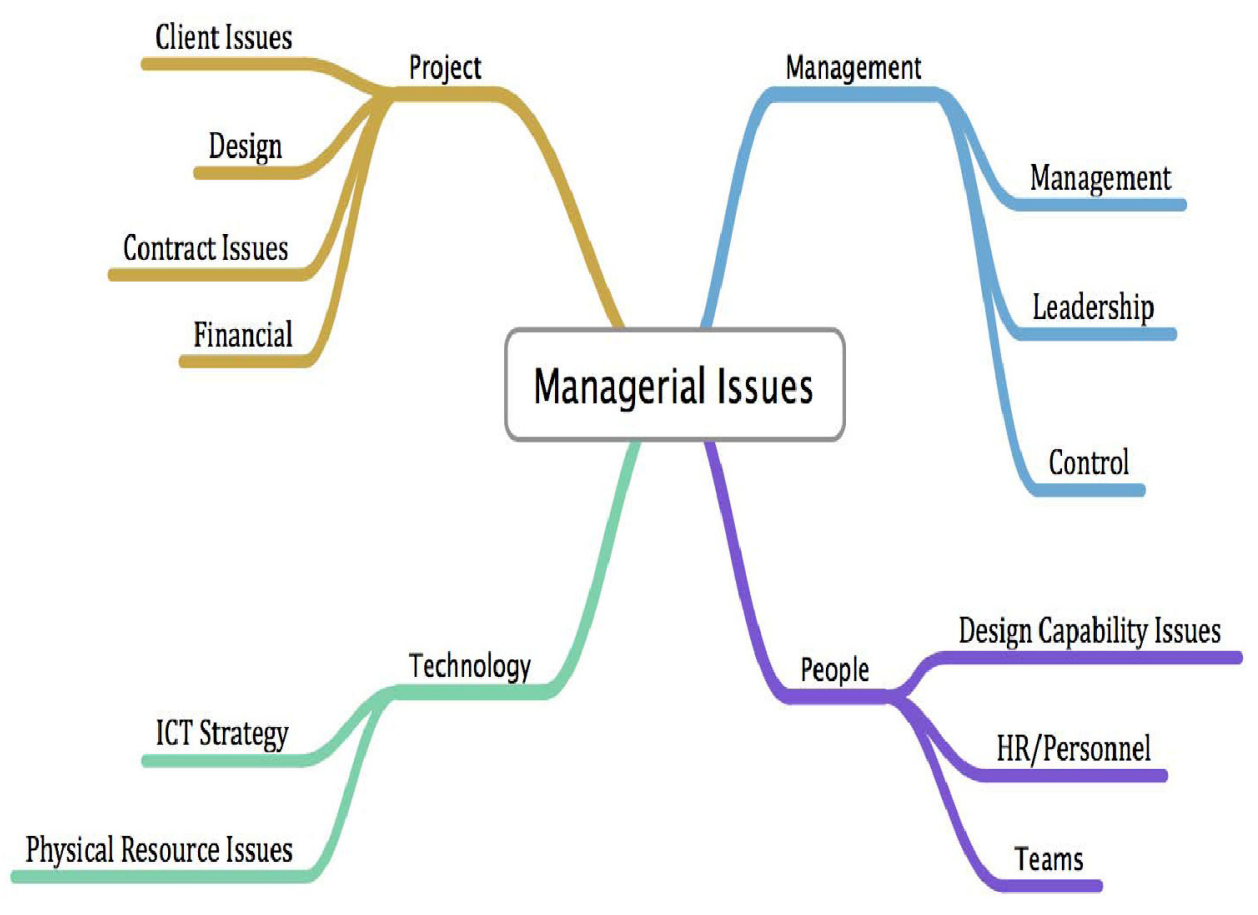

Figure 1. Research outcomes 


\subsection{Illustration of Research Outcomes}

The outline of the research outcomes for this study is shown in Figure 1 above. The framework supported by appropriate literature, illustrated below in Table 1, consists of four (4) main themes, and twelve (12) sub-themes. The outcomes are stated below where the discussion focuses on the sub-theme elements within each key theme. The discussion format used in this paper reflects the respondent's voice through a streamlined and articulated approach for reporting. Table 1 and 2 illustrate the respondent references for each sub-theme.

Consequently, the style adopted for reporting and illustrating the data is greatly influenced by Gonzalez, (2008) and also Daniels et al. (2007) and is discussed below, focusing on the raised research question and the resultant themes.

Table 1. Research question, themes and references

\begin{tabular}{|c|c|c|c|}
\hline $\begin{array}{l}\text { Research Question } \\
\text { What managerial challenges } \\
\text { and problems do design project } \\
\text { teams experience when } \\
\text { designing a TBM for a metro? }\end{array}$ & \multirow[t]{2}{*}{ Main Themes } & Sub-Themes & \multirow{2}{*}{$\begin{array}{l}\text { No. Refs } \\
15\end{array}$} \\
\hline \multirow{16}{*}{$\begin{array}{l}\text { What managerial challenges } \\
\text { and problems do design project } \\
\text { teams experience when } \\
\text { designing a TBM for a metro? }\end{array}$} & & Management & \\
\hline & \multirow[t]{4}{*}{ Management } & & 11 \\
\hline & & \multirow{2}{*}{$\begin{array}{l}\text { Leadersnip } \\
\text { Control }\end{array}$} & 12 \\
\hline & & & 38 \\
\hline & & Client Issues & 18 \\
\hline & Project & Design & 14 \\
\hline & & Contract Issues & 11 \\
\hline & & \multirow[t]{2}{*}{ Financial } & 13 \\
\hline & & & 56 \\
\hline & & $\begin{array}{l}\text { Design } \quad \text { Capability } \\
\text { Issues }\end{array}$ & 14 \\
\hline & \multirow[t]{3}{*}{ People } & HR/Personnel & 17 \\
\hline & & \multirow[t]{2}{*}{ Teams } & 11 \\
\hline & & & 42 \\
\hline & Technology & ICT Strategy & 13 \\
\hline & & $\begin{array}{l}\text { Physical } \\
\text { Issues }\end{array}$ & 16 \\
\hline & & & 29 \\
\hline
\end{tabular}

Table 2. Major themes and respondents

\begin{tabular}{ll}
\hline Major Themes & Respondent No. \\
\hline Management & $1,2,4,5,6,9,11,12,13$ \\
Project & $1,3,4,5,6,7,8,9,10,11,12,13$ \\
People & $1,2,4,5,6,7,8,9,10,11,12,13$ \\
Technology & $1,2,3,5,6,8,9,11$ \\
\hline
\end{tabular}

\section{Results}

The results are presented below using the research question as a pointer and supportive empirical evidence through indicated extractions as in Gonzalez (2008). Consequently, considering the research question-What managerial challenges and problems do design project teams experience when designing a TBM for a metro? The results are further indicated below, where each main theme is placed with every sub-theme. 


\subsection{Main Theme-Management}

\section{Management}

In terms of the sub-theme Management, one respondent (R6) indicated that,...management don't really understand the problems we face. They just want results - whatever it takes. Another respondent (R11) suggested that, ...It is exceptionally difficult to give them [management] what they want. It can't be done in the timeframe they've given us nor with the resources they give us. Further, another respondent (R13) stated that, ...I am not sure we are ready as yet. We're still planning. We have very tight timeframes.

\section{Leadership}

In terms of the sub-theme Leadership, one respondent (R9) indicated that, ...There's a distinct, and obvious, lack of leadership. We are swinging to one man's tune - and he's aggressive and not experienced enough. Another respondent (R12) suggested that, ...The tone is to do what he [manager] tells us and by whatever date. That's the leadership here. Further, another respondent (R4) stated that, ...Our system follows normal ways of working. Do what your told. That's it. This is compounded by another respondent (R1), who indicated that, ...I am not convinced that management have led any project before. They appear to lack the credibility and lineage of good engineers.

\section{Control}

In terms of the sub-theme Control, one respondent (R5) indicated that, ...Unquestionably, the process for control is absolutely centralised. Every decision has to be made through one or two individuals. Another respondent (R11) suggested that, ...Unfortunately, control rests with a few inexperienced managers. Sad really. Further, another respondent (R2) stated that, ...If only it worked. It is nonsense. No one can work like this. It's no wonder we are behind schedule. This is supported by another respondent (R6), who indicated that, ...Control is one thing, but to deliberately create this culture? They don't trust us as engineers.

\subsection{Main Theme-Project}

\section{$\underline{\text { Client Issues }}$}

In terms of the sub-theme Client Issues, one respondent (R12) indicated that,...The focus for us are the tangible outcomes. Those outcomes that can be measured against client requirements. Unfortunately, the interpretation by management isn't so great. Another respondent (R3) suggested that, ...Many client's assume we have everyone on board at the start. But here our asset management process means that we have to "streamline" the body count, as it were. Otherwise, it would become very messy and costly. Another respondent (R13) suggested that, ...The client usually doesn't totally understand big projects. That's why we're here. We don't have tell them everything. Further, another respondent (R8) stated that, ...You've got to be client faced in this job. They are seriously important to us. Some staff however, don't think the same way. However, another respondent (R4) suggested that, ...Our clients know we don't have the manpower on board. It's normal. But it can be extreme when the right personnel are not here or even when the stated individual in the bid document isn't here. It's too late then.

\section{Design}

In terms of the sub-theme Design, one respondent (R6) indicated that, ... We have a problem with design to be honest. It has taken an extraordinary amount of time to get where we are. Another respondent (R9) suggested that, ...It is fragmented. Too many chiefs and not enough people to do the work. Another respondent (R4) advised that, ...I blame the problem on the sub-contractor. They just don't take it seriously enough. It isn't managed properly here. In support of this, another respondent (R12) intimated that, ...The design team is everywhere. Not even in this country. It is incredibly difficult to manage. As a consequence we waste an awful lot of time trying to co-ordinate and then the design result is misunderstood.

\section{Contract Issues}

In terms of the sub-theme Contract Issues, one respondent (R11) indicated that, ...Our BIM section does a great job of managing. We haven't been caught yet. We have to be very specific about what we can charge the client. It's a question of balance. Another respondent (R1) suggested that, ...Not everything is reported. There are conditions. Fortunately, not everything has the same requirements - safety, contractual, reporting etc. So something's can be kept out of the limelight. This is further supported by another respondent (R3) who stated that, ... the contract is difficult o define properly, so we make do. We report what we can, but you know, it isn't exactly clear. 


\section{Financial}

In terms of the sub-theme Financial, one respondent (R13) denoted that, ... We need to ensure that they [staff] design the TBM as cost effectively as possible. But, I cannot see how we can improve our methods. It's difficult as it is. Another respondent (R1) suggested that, ...Our mission is to make money. Plain and simple. Another issue was raised by one respondent (R9) who stated, ... Our staff turnover is too much. I don't know how to stop it. It costs us so much. Lucky the client doesn't get the figures. But I'm sure they get it somehow. This unclear financial situation is further supported by another respondent (R5) who specified that, ...The finance's are controlled by one individual. We don't know what the budget is for our department. It's as if it is a secret. Underpinning this notion of tight financials, one respondent (R7) stated that, ... We have very little money. This place is screwed. It's illogical what they are doing on such a large project. To further expand on this issue, another respondent (R10) advised that, ...It is imperative that management show more respect for people and stop the incessant controls on money - personal and the project.

\subsection{Main Theme-People}

\section{Design Capability Issues}

In terms of the sub-theme Design Capability Issues, one respondent (R7) indicated that, ...What isn't understood effectively is the transition between signing a design contract and engaging design engineers. Another respondent (R10) suggested that, ...Are we qualified. That's a good question? Most of our staff are qualified in engineering, but few have any real knowledge about project management. That's the reality. Supporting this, another respondent (R12) showed that, ...Technically we are sound as a pound. However, there some holes in our offering. You know it's the usual highly experienced and highly qualified individual we desperately need but can't afford or can't get. So we make do. However, another respondent (R4) indicated, ...I've never been on a project where we have had 100\% jobs filled all the time. No, its more like $80 \%$. It's not good. Not good. We are weak as a consequence. It's difficult to progress and deliver.

\section{$\underline{\mathrm{HR} / \text { Personal }}$}

In terms of the sub-theme HR/Personal, one respondent (R7) specified that, ...We can only speculate on having the right people on board. Sometimes, we trick ourselves by only having a CV but no body. It can be extremely frustrating. Another respondent (R2) suggested that, ...At the start of the project we gave our trust that we can do it. Our staff will make sure we meet their approval. Another respondent (R13) submitted that, ...We are sometimes moved to take risks, even those that are considered professionally unsound. They revolve around putting people's CV's on our bidding documents that won't be available. Or, using people's names to boost our project. However, supporting this again, another respondent (R1) stated,...It is obvious, but no one tells the clients, that not all named people will be on the ground. We just say, things have changed in their circumstances. It's easy to blame them, rather than us. Adding to this notion, another respondent (R8) indicated that, ...We're always in a flux with engineers. You can't keep them all, and there is always those who feel they need to move on. It's difficult to manage. On the notion of training, one respondent (R9) affirmed that, ...No. We never train. They should already have done everything they need to be on the project. No. I think that training is very useful. Just not here and not now. We don't have the time. Training costs money and time off project. We make safety an issue, but even then, training is not carried out if it interferes with our main line of working. However, another respondent (R6) indicated unequivocally that, ...Money is tight. We know that. So we have to manage our budget carefully. Sometimes that means making some cuts or not paying someone's expenses or delaying it until we can. We don't have a choice.

\section{$\underline{\text { Teams }}$}

In terms of the sub-theme Teams, one respondent (R11) directed that, ...We have to form a unified team as soon as possible. This is a big task considering that here, there will be hundreds of people involved. Another respondent (R5) indicated that,...Unfortunately, we are a bunch of individuals. I really don't know how to improve the situation - it is too arduous. It's a very big job, I know that. This aspect is supported by another respondent ((R4), who stated, ...We are a team. We work together don't we? Since we are in a number of buildings separated across the city, only knows when we will be a team. Perhaps never. However, another respondent (R7) clearly indicates the cause of issue, ...It is management's fault we aren't a team. They do everything to prevent it. They move one against the other here. It's very personal and negative.

\subsection{Main Theme-Technology}

Physical Resource Issue

In terms of the sub-theme Physical Resource Issue, one respondent (R5) specified that, ...Our accommodation is 
first class. What the staff don't understand is that it is an awful lot of money that's been invested in it. And they don't want to be in it. However, This is supported by another respondent (R2) directed that, ...We are in separate buildings. Maybe being housed in one location may help. Another respondent (R9) stated that, ...Our technology is fragmented. It's very chaotic. We don't have the time to settle in, it's all go and no amount of technology will help us. This is also supported by another respondent (R3) who stated that, ...We have new technology computers, phones, cars. Unfortunately, they don't work together very well and we don't have the right software. It's just a mess.

\section{ICT Strategy}

In terms of the sub-theme ICT Strategy, one respondent (R8) indicated that, ... We have inherited the office site. It isn't ideal for our purposes. We could easily move to better office space, but the decision rests with someone in another country. Another respondent (R6) suggested that, ...There is no communication design. It's very ad-hoc. We are insignificant really. We can't work like this. It's like we are in the middle of a desert, with no connection to the world. However, another respondent (R11) states that, ...The IT strategy here is to create blocks. That's what I see. Nothing is more clearer. We get computers which breakdown within 24 hours, no software, no standardisation. I have to use my own personal computer in order to get anything done. It's very chaotic to work here. This is supported by another respondent (R1) who indicated that, ... There is no viable software strategy. Poor really. We cannot do our jobs here. Printers are unconnected and abandoned. It's no wonder we can't deliver the planned scope.

\section{Discussion}

In order to take this inquiry forward, the discussion concentrates on the raised question to help address some of the outcomes. Consequently, the main focus for this discussion are the characteristics revolving around the main themes-Management, Project, People and Technology.

\subsection{Management}

The influence of project complexity (Kaming, Olomolaiye, Holt, \& Harris, 1997), which appeared to show managerial decision incongruence and personal divisory reactions from inexperienced or intransient project management, may underpin the consequent delays to the project schedule through poor coordination (OGC, 2010). Further, inadequate and improper project preparation (Oyegoke, 2001) and its operation resulted in the ineffective programme management of the project activities to date (Owen et al., 2010). However, it would appear that there is also an inadequate managerial execution (Wainaina, 2008) through an authority-compliance leadership style (Vroom \& Jago, 1988), which is not considered appropriate by staff. Consequently, the level of project competency (Global Alliance for Project Performance Standards, 2007) shown by the project management in terms of context and personnel collaboration (Kadefors, 2011) appears to be disruptive, intransient and incapable of leading to an effective project outcome (Latham, 1994). This complex construction project requires additional management competencies (Ahadzie, Proverbs \& Olomolaiye, 2008) to control the project. Consequently, the project management have not been observed to hold, embrace or articulate and present management behaviour which is seen as proactive, appropriate or relevant to project requirements or personnel needs (Anvuur \& Kumaraswamy, 2007). In order to help with this management failing, directing the project more effectively through scenario planning may help (Lindgren \& Bandhold, 2003).

Project leadership demands more than just resource focus and attention to programme details (Carter, 1988). It demands an engagement with engineering staff passions and communication (Geaney, 1995). In terms of this project, there would appear to be reluctance by project management to provide appropriate leadership (Morris and Pinto, 2004) and the application of proper project skills (Engwall, 2003) leading to staff perceptions of mistrust and scepticism (Adler, 2005).

\subsection{Project}

Client knowledge of the project only comes through the project managers and this is perceived as a major barrier to operationalising the project effectively through a negative management culture (Clegg, 1989). In essence, the way the project is run managerially has implications for client demands (Appel, 1993) and for the project outcomes and the client-project management relationships (Davis \& Pharro, 2003). Design considerations appears to be compromised by inadequate project management (Morris, 1994); leading to contractual failures; which may be mediated through more effective client relationships (Dyer \& Singh, 1998) - thus increasing the time schedule and costs of the project and also leading to further conflict (Hunter \& Hoenig, 1992) requiring resolution. Further, it would appear that a more pertinent and focused project recruitment process should be introduced (Loosemore, Dainty \& Lingard, 2003) which also considers and examines how staff are treated when 
on-site (Huselid, 1995).

Another major issue is the management behaviour in terms of hiding project outcomes from the client - a predisposed dysfunctional culture (Bate, 1994) - giving the illusion of managerial flexibility (Markish \& Willcox, 2003). This happens in many construction projects and is a managerial behaviour that carries significant risk for the client (Chapman, 2001) whilst attempting to recognise the need for the designer to maximise return on investments of capital assets (Pennanen, Ballard \& Haahtela, 2011). Consequently, this must be modified in line with good project management practices (Koskela, Huovila \& Leinonen, 2002).

\subsection{People}

As a result of this inquiry, the perceived impact of the possible negative effect of the developed project management culture (Hofstede \& Hofstede, 2005) has to be taken into account along with the reduced quality of team interaction (Sacks, Koskela \& Dave, 2010) between project management and the design engineers. This needs to be addressed using more integrated management processes (Badreddine, Romdhane \& Amor, 2009) such as teambuilding (James, 2005); project management training in strategy project engagement (Arttoa, Kujalab, Dietrichb, \& Martinsuo, 2008); in order to meet the established needs of project engineering staff (Roberts, 2005). Further, by utilising appropriate program management techniques in order to reduce project confusion and enhance financial and process efficiency (Martinsuo \& Lehtonen, 2007a) this will reduce the impact of a traditional project hierarchal/patriarchal approach (Kerzner, 2003).

From an HR perspective, the capability of the design team is seriously brought into question by constant movement of engineers into and out of the project - raising distributed team issues (Hinds \& Bailey, 2003). This indicates little time for strengthening of relationships, building trust and communication (Lau \& Rowlinson, 2011); and providing appropriate administrative project support.

An obvious managerial discontinuity is the lack of training maintained by the project managers possibly through indifference to developing personnel further signifying "non-interoperability" inhibitors affecting the efficacy of the project (Moore \& Dainty, 2001). In terms of the project requirements, the project appears to lack the collective knowledge and skill sets for the discovered project tasks resulting from inappropriate team decisions (Raiden, Dainty \& Neale, 2004). Particular care needs to be given by the project management to teambuilding activities (Lewis, 2004) in order to secure a more effective design outcome. This is especially so as the leadership prerogative of the project management (Levy, 2007) is to engender a sense of togetherness and purpose, seen empirically lacking by the project engineering staff.

Further, collaboration between the client, the PMC and the contractor is a difficult situation to manage (Eriksson, Nilsson, \& Atkin, 2008) as negative responses surrounding trust, scheduling and power were raised. This can be mitigated using appropriate culture/knowledge management methodologies (Kane, Ragsdell, \& Oppenheim, 2006) that seek to enhance the experiences of staff and to ensure an equitable working environment, whilst building teamwork (Walker, 1996).

\subsection{Technology}

Management appears to support the notion of utilising an incomplete ICT system that nurtures division and provides little in terms of an effective platform for work co-ordination (Brewer \& Gajendran, 2009). Further, of possible concern is the relationship to the defined ICT use (contained in the bidding document) and the actual presentation of such resources. The client could expect better ICT involvement (Linderoth \& Jacobsson, 2008) in order to underpin design strategies. The ICT strategy (Blochle et al., 2013) needs to be reaffirmed, developed and applied to ensure the capability of the design teams. ICT is often the central resource connecting different disciplines of the project together (Gunasekaran et al., 2001). In this project, it has been reported that this aspect is compromised, and this affects the efficacy of the management of the project and its investment (Ekstrom \& Bjornsson, 2003) and is considered wholly questionable (Dadayan, 2006) in its scope and application.

Further, there does not appear to be a defined human resource development strategy (Raidén \& Dainty, 2006) that ensures the changing HR demands of the design and construction of the metro are met consistently, resulting in reduced employee turnover (Arthur, 1994); enhanced personal skill portfolio (Maloney, 1997); and a more effective workforce (Brandenburg \& Byrom, 2006).

\section{Conclusion}

The project managers of this large metro project are engaged wholly with persistent established practices and routines (Green \& May, 2005) that could be seen as out-dated, unbending, patriarchal, and destabilising to the project as a whole. This also illustrates clearly that the project is managed in a dominant blame-culture (Martin, 2002). The project management's responsibility to prepare, design and bring to bear appropriate solutions 
(Sambasivan \& Soon, 2007) to solve the issues at site. In so doing project management will provide a more enriched managerial environment (Doloi, 2013) for engineers to trust and rely on, whilst undertaking fairly difficult and complex jobs in the design of a metro.

Physical resources are also brought into question by the staff. Issues of multi-site approach with groups of engineers are in different places, or even different members of the same group. This explains why team-building is an issue, the management of human resources is difficult and that managing ICT is not upto expected standards.

The project management may need to point to contemporary developments in project management in order to understand how design-engineers need a more engaged system of operation (Nassar \& AbouRizk, 2014) and need to plan and develop how to use human capital and other resources to equitably deliver a successful project outcome.

\section{Further Work}

Since this inquiry assessed the little known area of TBM design engineer's perceptions of a metro project management, the research orientation could be extended to include all engineers for their views of the project management. Further implications could be drawn from such work and evaluations made as to how these could be mitigated in the present structuring and management of construction projects.

\section{References}

Adler, T. R. (2005). The Swift Trust Partnership: A Project Management Exercise Investigating the Effects of Trust and Distrust in Outsourcing Relationships. Journal of Management Education, 29(5), 714-737. http://dx.doi.org/10.1177/1052562905277304

Ahadzie, D. K., Proverbs, D. G., \& Olomolaiye, P. (2008). Towards developing competency-based measures for construction project managers: Should contextual performance behaviors be distinguished from task performance behaviors? International Journal of Project Management, 26(6), 631-645. http://dx.doi.org/10.1016/j.ijproman.2007.09.011

Andersen, E. S., Birchall, D., Jessen, S. A., \& Money, A. H. (2006). Exploring critical success factors. Baltic Journal of Management, 2, 127-147.

Anderssen E. (2003). Understanding your project organisation's character. International Journal of Project Management, 34(4), 4-11.

Anvuur, A. M., \& Kumaraswamy, M. M. (2007). Conceptual Model of Partnering and Alliancing. Journal of Construction Engineering and 225-234. http://dx.doi.org/10.1061/(ASCE)0733-9364(2007)133:3(225)

Appel, M. (1993). Partnering - new dimensions in dispute prevention and resolution. Arbitration Journal, 48(2), 47-51.

Arthur, J. B. (1994). Effects of human resource systems on manufacturing performance. Academy of Management Journal, 37(3), 670-687. http://dx.doi.org/10.2307/256705

Arttoa, K., Kujalab, J., Dietrichb, P., \& Martinsuo, M. (2008). What is project strategy? International Journal of Project Management, 26(1), 4-12. http://dx.doi.org/10.1016/j.jproman.2007.07.006

Bailey, J. (2008). First steps in qualitative data analysis: Transcribing. Family Practice, 25(2), 127-131. http://dx.doi.org/10.1093/fampra/cmn003

Ballard, G., \& Howell, G. (2003). Lean Project Management. Building Research and Information, 31(2), 119-133.

Balshem, M. (1991). Cancer, Control and Causality: Talking about Cancer in a Working-Class Community. American Ethnologist, 18(1), 152-172. http://dx.doi.org/10.1525/ae.1991.18.1.02a00070

Bate, P. (1994). Strategies for cultural change. Oxford: Butterworth Heinemann; UK.

Badreddine, A., Romdhane, T. B., \& Amor, N. B. (2009). A New Process-Based Approach for Implementing an Integrated Management System: Quality, Security, Environment. Proceedings of the International MultiConference of Engineers and Computer Scientists 2009 Vol II IMECS 2009, March 18-20, Hong Kong.

Benn, N., Buckingham, S., Domingue, J., \& Mancini C. (2008). Ontological Foundations for Scholarly Debate Mapping Technology. 2nd International Conference on Computational Models of Argument (COMMA '08); 
28-30 May, Toulouse, France.

Blöchle, M. Iglár, B., Basciotti, D., \& Page, P. (2013). Developing a Strategy for the Implementation of ICT in Energy Efficient Neighbourhoods. CT4S 2013: Proceedings of the First International Conference on Information and Communication Technologies for Sustainability, ETH Zurich, February 14-16.

Brandenburg, S. G., \& Byrom, K. (2006). Strategic Management of Human Resources in Construction. Journal of Management in Engineering, 22(2), 89-96. http://dx.doi.org/10.1061/(ASCE)0742-597X(2006)22:2(89))

Brewer, G., \& Gajendran, T. (2009). Emerging ICT trends in construction project teams: A Delphi survey. ITcon. 14, Technology Strategies for Collaborative Working, 81-97. Retrieved from http://www.itcon.org/2009/09

Brown, S., \& Eisenhardt, K. (1997). The art of continuous change: linking complexity theory and time-paced evolution in relentlessly shifting organizations. Administrative Science Quarterly, 42(1), 1-34.

Bryman, A. (2001). Social Research Methods. Oxford; UK: Oxford University Press.

Buston, K. (1999). NUD*IST in action: its use and its usefulness in a study of chronic illness in young people. In A. Bryman, R. G. Burgess (Eds.), Analysis and Interpretation of Qualitative Data (Vol 3, pp. 183-202). London, UK: Sage Publications.

Carman, J. M. (1990). Consumer perceptions of service quality: An assessment of the SERVQUAL dimensions. Journal of Retailing, 66(1), 33-55.

Carter N. (1988). The project manager: An emerging professional. Journal of Information Systems Management, 5(4), 8-14. http://dx.doi.org/10.1080/07399018808962935

Cassell, C., \& Symon, G. (2004). Essential Guide to Qualitative Methods in Organizational Research. London, UK: Sage Publications.

Cayla, J., \& Eckhardt, G. M. (2007). Asian brands without borders: Regional opportunities and challenges. International Marketing Review, 24(4), 444-456. http://dx.doi.org/10.1108/02651330710761017

Chapman, R. J. (2001). The Controlling Influences on Effective Risk Identification and Assessment for Construction Design Management. International Journal of Project Management, 19(3), 147-160. http://dx.doi.org/10.1016/S0263-7863(99)00070-8

Chapman, C., \& Ward, S. (1995). Project Risk Management. New York; US: John Wiley \& Sons.

Cicmil, S. (2005). Reflection, participation and learning in project environments: A multiple perspective agenda. In P. E. D. Love, P. S. W. Fong, \& Z. Irani (Eds.), Management of knowledge in project environments. Oxford; UK: Elsevier.

Clegg, S. (1989). Frameworks of power. London, UK: Sage.

Cohen, J. (2010). Integrated Project Delivery: Case Studies. California; US: AIA National, AIA California Council, AGC California and McGraw-Hill.

Coyne, I. T. (1997). Sampling in qualitative research. Purposeful and theoretical sampling; merging or clear $\begin{array}{llll}\text { boundaries? } & \text { Journal } & \text { of }\end{array}$ http://dx.doi.org/10.1046/j.1365-2648.1997.t01-25-00999.x.

Crawford, L., Pollack, J., \& England, D. (2006). Uncovering the trends in project management: Journal emphases over the last 10 years. International Journal of Project Management, 24, 175-184.

Cunningham, P. A. (2014). Exploring the efficacy of consensus-based decision-making: A pilot study of the Cloughjordan Ecovillage, Ireland. International Journal of Housing Markets and Analysis, 7(2), 233-253. http://dx.doi.org/10.1108/IJHMA-06-2013-0040

Dadayan, L. (2006). Measuring Return on Government IT Investments. Proceedings of the 13th European Conference on Information Technology Evaluation, Genoa, Italy, 28-29 September.

Daniels, J. A. et al., (2007). The Successful Resolution of Armed Hostage/Barricade Events in Schools: A Qualitative Analysis. Psychology in the Schools, 44(6), 601-613. http://dx.doi.org/10.1002/pits.20250

Davenport, T. H., De Long, D. W., \& Beers, M .C. (1998). Successful knowledge management projects. Sloan Management Review. Winter, 39, 43-57.

Davis, T., \& Pharro, R. (2003). The Relationship Manager: The Next Generation of Project Management. UK: Gower Publishing.

Derelov, M. (2008). Qualitative modelling of potential failures: On evaluation of conceptual design. Journal of 
Engineering Design, 19(3), 201-215.

Doloi, H. (2013). Cost Overruns and Failure in Project Management: Understanding the Roles of Key Stakeholders in Construction Projects. Journal of Construction Engineering Management, 139(3), $267-279$. http://dx.doi.org/10.1061/(ASCE)CO.1943-7862.0000621

Duranti, A. (2007). Transcripts, like shadows on a wall. Mind, Culture and Activity, 13(4), 301-310.

Dyer, J. H., \& Singh, H. (1998). The relational view: Cooperative strategy and sources of inter-organisational competitive advantage. Academy of Management Review, 23(4), 660-679.

Ekstrom, M. A. \& Bjornsson, H. C. (2003). Evaluating IT investments in Construction-Accounting for strategic flexibility. CIFE Technical Report \#136, Stanford University, US.

Engwall, M. (1998). The ambiguous project concept(s). In R. A. Lundin, \& C. Midler (Eds.), Projects as arenas for renewal and learning processes. Boston, MA, US: Kluwer Academic Publishers.

Engwall, M. (2003). No Project is an island: Linking projects to history and context. Research Policy, 32(5), 789-809. Retrieved from http://econpapers.repec.org/RePEc:eee:respol:v:32:y:2003:i:5:p:789-808

Eriksson, E., Nilsson, T., \& Atkin, B. (2008). Client perceptions of barriers to partnering. Engineering, Construction and Architectural Management, 15(6), 527-539.

Fink, A. S. (2000). The Role of the Researcher in the Qualitative Research Process. A Potential Barrier to Archiving Qualitative Data. Forum: Qualitative Social Research, 1(3), Art.4, December.

Flyvbjerg, B., Bruzelius, N, \& Rothengatter, W. (2003). Megaprojects and risk. An anatomy of ambition. Cambridge; UK: Cambridge University Press.

Foley, S., \& MacMillan, S. (2005). Patterns of interaction in construction team meetings. CoDesign, 1(1), 19-37.

GAAPS. (2007). Global Alliance for Project Performance Standards. A framework for performance based competency standards for Global Level 1 and 2 project managers.

Garvin, D. (1998). The Processes of Organization and Management. Sloan Management Review, July.

Geaney, M. M. (1995). The right skills for the job. Computing Canada, 21(24), 8-13.

Glaser, B. G. (2004). Remodeling Grounded Theory. The Grounded Theory Review: An international Journal, $4(1), 1-24$

Glaser, B. G. (1992a). Basics of grounded theory analysis: Emergence vs. forcing. Mill Valley, CA, US: Sociology Press.

Glaser, B. G., \& Strauss, A. L. (1967). The Discovery of Grounded Theory: Strategies for qualitative research. Chicago, US: Aldine.

Gobeli, D., Koenig, H., \& Bechinger, I. (1998). Managing conflict in software development teams: A multilevel analysis. Journal of Product Innovation Management, 15(5), 423-435.

Gonzalez, C. (2008). Conceptions of, and approaches to, teaching online: A study of lecturers teaching postgraduate distance courses. Higher Education, 57(3), $299-314$. http://dx.doi.org/10.1007/s10734-008-9145-1

Gray, J., \& Wilcox, B. (1995). Good Schools, Bad Schools. Milton Keynes, UK: Open University Press.

Green, S., \& May, S. C. (2005). Lean construction: arenas of enactment, models of diffusion and the meaning of 'leanness'. Building Research and Information, 33(6), 498-511.

Guest, G., Bunce, A., and Johnson, L. (2006). How Many Interviews Are Enough?: An Experiment with Data Saturation and Variability. Field Methods, 18(1), 59-82.

Gunasekaran, A., \& Love, P. E. D. (1998). Concurrent engineering: A multi-Disciplinary approach for construction. Logistics Information Management, 11(5), 295-300.

Gunasekaran, A., Love, P. E D., Rahimi, F., \& Miele, R. (2001). A Model for Investment Justification in Information Technology Projects. International Journal of Information Management, 21(5), 349-364.

Harrel, G. D., \& Fors, M. F. (1995). Marketing services to satisfy internal customers. Logistics Information Management, 8(4), 22-27. http://dx.doi.org/10.1108/09576059510091887

Harwood, T. G., \& Garry, T. (2003). An overview of content analysis. The Marketing Review, 3(4), $479-498$. http://dx.doi.org/10.1362/146934703771910080 
Hastings, C. (1995). Building the culture of organizational networking: Managing projects in the new organization. International Journal of Project Management, 13(4), 259-263. http://dx.doi.org/10.1016/0263-7863(95)00029-P

Hill, C. E., Thompson, B. J., \& Williams, E. N. (1997). A guide to conducting consensual qualitative research. The Counseling Psychologist, 25, 517-572.

Hinds, P. J., \& Bailey, D. E. (2003). Out of sight, out of sync: Understanding conflict in distributed teams. Organization Science, 14(6), 615-632.

Hofstede, G., \& Hofstede, G. J. (2005). Cultures and Organizations. Software of the Mind (2nd ed.). New York, US: McGraw-Hill.

Horvath, I., Rusak, Z., \& Duhovnik, J. (2007). Computational methods to support sketching, reverse engineering and optimisation of shapes. Journal of Engineering Design, 18(5), 391-394.

Hunter, K., \& Hoenig, J. (1992). Dispute resolution and avoidance techniques in the construction-industry. Arbitration Journal, 47(3), 16-18.

Huselid, M. A. (1995). The impact of human resource management practices on turnover, productivity and corporate financial performance. Academy of Management Journal, 38(3), 635-672.

Jaafari A. (2003). Project management in the age of complexity and change. International Journal of Project Management, 34(4), 47-57.

James, P. (2011). The creative university in the Thai creative economy. Research in Business and Economics Journal, 3.

James, P. (2005). Total Quality Management in Asia: Practices for the 21st Century. Singapore: Pearson.

Kadefors, A. (2011). Organizing Collaboration In Construction Projects-Formal Models Meeting Practitioner Perspectives. Management and Innovation for a Sustainable Built Environment. 20-23 June 2011, Amsterdam, The Netherlands.

Kaming, P. F., Olomolaiye, P. O., Holt, G. D., \& Harris, F. C. (1997). Factors influencing construction time and cost overruns on high-rise projects in Indonesia. Construction Management and Economics, 15(1), 83-94. http://dx.doi.org/10.1080/014461997373132

Kane, H., Ragsdell, G., \& Oppenheim, C. (2006). Knowledge Management Methodologies. The Electronic Journal of Knowledge Management, 4(2), 141-152.

Keegan, A. E., \& Den Hartog, D. N. (2004). Transformational leadership in a project-based environment: a comparative study of the leadership styles of project managers and line managers. International Journal of Project Management, 22(8), 609-617. http://dx.doi.org/10.1016/j.jproman.2004.05.005

Kerzner, H. (2003). Strategic planning for a project office. Project Management Journal, 34(2), 13-25. http://dx.doi.org/10.1080/014461997373132

Kerzner, H. (1998). Project management: A systems approach to planning, scheduling and controlling. New York, US: van Nostrand Reinhold.

Koerber, A., \& McMichael, L. (2008). Qualitative Sampling Methods: A Primer for Technical Communicators. Journal of Business and Technical Communication, 22(4), 454-473.

Koot, W., \& Sabelis, I. (2002). Beyond complexity. Paradoxes and coping strategies in managerial life. Amsterdam, The Netherlands: Rozenberg Publishers.

Koskela, L. (2003). Is structural change the primary solution to the problems of construction? Building Research \& Information, 31(2), 89-96.

Koskela, L., Huovila, P., \& Leinonen, J. (2002). Design management in building construction: Forum theory to practice. Journal of Construction Research, 3(1), 1-16. http://dx.doi.org/10.1142/S1609945102000035

Langfred, C. W., \& Moye, N. A. (2004). Effects of Task Autonomy on Performance: An Extended Model Considering Motivational, Informational, and Structural Mechanisms. Journal of Applied Psychology, 89(6), 934-945.

Latham, M. (1994). Constructing the team. London, UK: HMSO.

Lau, E., \& Rowlinson, S. (2011). The implications of trust in relationships in managing construction projects. International Journal of Managing Projects in Business, 4(4), 633-659. 
Lee, T., Kim D., \& Lee, D. (2011). A competency model for project construction team and project control team. KSCE Journal of Civil Engineering, 15(5), 781-792.

Levy, S. M. (2007). Project Management in Construction. New York, NY, US: McGraw-Hill.

Lewis, J. P. (2004). Team-Based Project Management. US: Beard Books.

Linderoth, H. C. J., \& Jacobsson, M. (2008). Understanding adoption and use of ICT in construction projects through the lens of context, actors and technology. CIB W78, International Conference on Information Technology in Construction, Santiago, Chile.

Lindgren, M., \& Bandhold, H. (2003). Scenario Planning: The Link between Future and Strategy. Basingstoke, UK: Palgrave/Macmillan.

Lindgren, M., \& Packendorff, J. (2005). Projects and prisons. Hampshire; UK: Palgrave MacMillan.

Loosemore, M., Dainty, A. \& Lingard, H. (2003). Human resource management in construction projects - strategic and operational aspects. London, UK: Taylor and Francis Ltd.

Lynn, G. (1998). New product team learning: Developing and profiting from your knowledge capital. California Management Review, 40(4), 74-94.

Maloney, W. (1997). Strategic Planning for Human Resource Management in Construction. Journal of Management Engineering, 13(3), 49-56. http://dx.doi.org/10.1061/(ASCE)0742-597X(1997)13:3(49)

Markish, J., \& Willcox, K. (2003). Value-based multi-disciplinary techniques for commercial aircraft system design. AIAA Journal, 4l(10), 2004-2012.

van Marrewijk, A., \& Veenswijk, M. (2006). The culture of project management: understanding daily life in complex megaprojects. Essex, UK: Prentice-Hall.

Martin, J. (2002). Organizational culture mapping the terrain. London, UK: Sage.

Martinsuo, M., \& Lehtonen, P. (2007a). Program initiation in practice: Development program initiation in a public consortium. International Journal of Project Management, 25(4), 337-345. http://dx.doi.org/10.1016/j.ijproman.2007.01.011

McAnulty, S., \& Baroudi, B. (2010). Construction Challenges in Remote Australian Locations. Association of Researchers in Construction Management (ARCOM) Conference, September 2010, Leeds; UK.

Mintzberg, H. (1980). A Structure in 5's, A Synthesis of Research in Organization Design, Management Science, March, 26(3), 322-341.

Moore, D., \& Dainty, A. (2001). Intra-team Boundaries as inhibitors of performance improvement in UK design and build projects: A call for change. Construction Management and Economics, 19(6), 559-562. http://dx.doi.org/10.1080/01446190110055508

Morris, P. G. (1994). The management of projects. New York, US: Telford.

Morris, P., \& Pinto, J. (Eds.). (2004). The Wiley guide to managing projects. New Jersey, US: Wiley.

Nassar, N., \& AbouRizk, S. (2014). Practical Application for Integrated Performance Measurement of Construction Projects. Journal of Management Engineering, March. http://dx.doi.org/10.1061/(ASCE)ME.1943-5479.0000287

OGC. (2010). OGC, Portfolio, Programme and Project Management Maturity Model P3M3 version 2.1. Office Of Government Commerce.

Olson, G. M., \& Olson, J. S. (2000). Distance matters. Human-Computer Interaction, 15, 139-178.

Onwuegbuzie, L., \& Collins. (2012). Qualitative Analysis Techniques for the Review of the Literature. The Qualitative Report, 17, 1-28.

Owen, R., Amor, R., Palmer, M., Dickson, J., Tatum, C. B., Kazi, A. S., Prins, M., Kivinieni, A., \& East, B. (2010). Integrated Design and Design Solutions. Architectural and Design Management, 6(4), 232-240. http://dx.doi.org/10.3763/aedm.2010.IDDS1

Oyegoke, A. S. (2001). UK and US construction management contracting procedures and practices: A comparative study. Engineering, Construction and Architectural Management, 8(5/6), 403-417.

Pena-Mora, F., Sriram, D., \& Logcher, R. (1995). Design Rationale for computer-Supported Conflict Mitigation. Journal of Computing in Civil Engineering, 9(1), 57-72. 
Pennanen, A., Ballard, G., \& Haahtela, Y. (2011). Target costing and designing to targets in construction. Journal of Financial Management of Property and Construction, 16(1), 52-63.

Raidén, A. B., \& Dainty, A. (2006). Human resource development in construction organisations: An example of a "chaordic" learning organisation? The Learning Organization, 13(1), 63-79.

Raiden, A., Dainty, B., \& Neale, A. (2004). Current barriers and possible solutions to effective project team formation and deployment within a large construction organization. International Journal of Project Management, 22(4), 309-316.

Reeves, T. K., \& Harper, D. (1981). Surveys at Work. London, UK: McGraw-Hill.

Reisman, C. K. (1993). Narrative Analysis. London, UK: Sage Publications.

Ritchie, J., \& Lewis, J. (2003). Qualitative Research Practice: A Guide for Social Science Students and Researchers. London, UK: Sage Publications.

Roberts, H. (2005). Creating motivation, identifying incentives and enablers, and encouraging staff development. Community Eye Health, 18(56), 122-124.

Rogers, E. M. (1995). Diffusion of Innovations. New York, US: The Free Pres.

Sacks, R., Koskela, L., \& Dave, B. A. (2010). Interaction of lean and building information modeling in construction. Journal of construction Engineering and Management, 136(9), 968-980. http://dx.doi.org/10.1061/(ASCE)CO.1943-7862.0000203

Ryan, G. W., \& Bernard, H. R. (2003). Techniques to Identify Themes. Field Methods, 15(1), 85-109. http://dx.doi.org/10.1177/1525822X02239569

Sambasivan, M., \& Soon, Y. W. (2007). Causes and effects of delays in Malaysian construction industry. International Journal of Project Management, 25, 517-526.

Saurin, T., Formoso, C., \& Guimarães, L. (2004). Safety and Production: An Integrated Planning and Control Model. Construction Management and Economics, 22(2), 159-169.

Sauser, B. J., Reilly, R., \& Shenhar, A. J. (2009) Why projects fail? How contingency theory can provide new insights: A comparative analysis of NASA's Mars Climate Orbiter loss. International Journal of Project Management, 27(7), 665-679.

Strauss, A. L., \& Corbin, J. (1990). Basics of qualitative research: Grounded theory, procedures and techniques. Newbury Park, US: Sage Publications.

Szulanski, G. (1996). Exploring internal stickiness: Impediments to the transfer of best practice within the firm. Strategic Management Journal, 17(2), 27-43. http://dx.doi.org/10.1002/smj.4250171105

Teece, D. J., Pisano, G., \& Shuen, A. (1997). Dynamic capabilities and strategic management. Strategic Management Journal, 18(7), 509-533

Thomsen, C. Darrington, J. Dunne, D., \& Lichtig, W. (2009). Managing Integrated Project Delivery, Construction Management Association of America (CMAA). Va, US: McLean.

Tull, D. S., \& Hawkins, D. I. (1990). Marketing Research: Measurement and Method. UK: Macmillan.

Yoo T., \& Chang H. (2013). The IT convergence framework design in the internet of things environment. EURASIP Journal on Wireless Communications and Networking. http://dx.doi.org/10.1186/1687-1499-2013-53

Young, T. (1998). The handbook of project management: A practical guide of effective policies and procedures. London, UK: Institute of Directors, Kogan Page.

Vroom, V. H., \& Jago, A. G. (1988). The new leadership: managing participation in organizations. Englewood Cliffs (NJ), US: Prentice-Hall.

Wainaina, G. (2008). Time and Cost Overruns in Power Projects in Kenya: A Case Study of Kenya Electricity Generating Company Limited. $4^{\text {th }}$ International Operations Research Society of Eastern Africa (ORSEA) Conference, 2008, ARCHWAY Technology Management Ltd.

Walker, A. (1996). Project Management in Construction (3rd ed.). London, UK: Blackwell Science.

Walsh, S. P., White, K. M., \& Young R. M. (2008). Over-connected? A qualitative exploration of the relationship between Australian youth and their mobile phones. Journal of Adolescence, 31(1), 77-92. http://dx.doi.org/10.1016/j.adolescence.2007.04.004 


\section{Copyrights}

Copyright for this article is retained by the author(s), with first publication rights granted to the journal.

This is an open-access article distributed under the terms and conditions of the Creative Commons Attribution license (http://creativecommons.org/licenses/by/3.0/). 